\title{
People Management and Emerging Market Multinationals
}

\author{
Adrian Wilkinson, Geoffrey Wood, and Mehmet Demirbag
}

\begin{abstract}
There is a very extensive body of literature on how multinationals manage their people in different national contexts. However, the bulk of this literature focuses on the case of multinationals from the advanced industrial economies, and to a considerable extent, the United States. Very much less has been written on multinationals with their country of origin being an emerging market, and what there has focuses on a very limited number of preferred cases. The growing importance of emerging economies has lead to an upsurge of strategy research on the topic (Wright, Filatotchev, Hoskisson and Peng, 2005); however, research on HRM has not paid enough attention to Emerging Market Multinational Enterprises (EMNEs). Many EMNES tend to be smaller in size with considerably lesser resources and international experience than their counterparts from developed markets limiting their ability to transfer management practice across their subsidiaries (Thite, Wilkinson, \& Shah, 2012), although there are important exceptions to this rule. This introductory article seeks to contribute to the emerging body of literature in this area, through seeking to encourage fresh insights particularly on the varieties of people management encountered in different national contexts.
\end{abstract}

Correspondece to: Geoffrey Wood, Professor of International Business, Warwick Business School, University of Warwick, Coventry, CV4 7AL UK, Phone: +44 (0)24 765 24502, Email: Geoffrey.Wood@wbs.ac.uk.

Emerging market MNCs have become increasingly prominent - and at times, controversial - within both the developing and developed world. This has encompassed such a diverse range of activities such as takeovers of failing Western firms, the buying up of land and mineral resources in Africa, and the establishment of (often) low cost manufacturing companies in target markets (or in countries with which such markets enjoy free trade agreements) in order to circumnavigate remaining tariff barriers. Whilst the diversity of such activity makes it difficult to draw out general trends, a few issues are of particular importance. The first is the political dimension of MNC activity, an issue relatively neglected in the business and management literature. Where MNCs originate in less democratic countries, relations with parent country governments and senior 
politicians may be closer and/ or more opaque. And, if pressures toward public accountability at home are weaker, this gives such firms more room for maneuver in reaching deals with repressive or corrupt political elites abroad. Secondly, whilst the existing literature on managing people in MNCs primarily focuses on the challenges of managing locals and a relatively small number of skilled expatriates, Chinese MNCs have increasingly brought semi- and unskilled labor with them into developing countries in Africa; this development has far reaching organizational, developmental, political and, even, demographic dimensions. Thirdly, decisions to enter markets appear often not to be prompted either by the prospect of low cost labor or particular skills sets, but rather, to secure access to consumers and to raw materials in an age of peak oil and generally escalating minerals prices.

There are a number of different classifications with regard to emerging countries (for example, World Bank, UNCTAD, 2006; 2010; FTSE index, 2012; MSCI Barra Index, 2012; Hoskisson, Wright, Filatotchev, \& Peng, 2013) but there is no consensus between them. Emerging countries are commonly defined as "low-income, rapid-growth countries using economic liberalization as their primary engine of growth" (Hoskisson, Eden, Lau, \& Wright, 2000). Although many commentators focus on the BRIC countries (i.e., Brazil, Russia, India, and China) or VISTA countries of Vietnam, Indonesia, South Africa, Turkey and Argentina (Hennart, 2012), others such as Mexico and Thailand has also increased their respective outward foreign direct investment (OFDI) (Deng, 2012). FDI by developing country firms is not a new phenomenon (Wells, 1983; Lall, 1983, Lecraw, 1993; Kumar and McLeod, 1981) but their global reach and the pace and pattern has recently attracted a great deal of attention from academia (Khanna and Palepu 2006; 
Aulakh 2007; Jormanaien and Kovashnikov 2012; Gaur and Kumar 2010; CuervoCazurra, 2012) and business media (Business Week, 2006; Economist, 2008, Girod, Belin and Thomas, 2009; $B C G$, 2012). Firms from emerging countries have dramatically grown in the global markets recently. For example, while only 19 firms from emerging and developing economies were featured in the Fortune Global 500 list in 1990, this number increased to 123 in 2011. Amongst these global challengers, some have even grown to be the market leaders in their respective industries. In terms of overall revenue, for instance, Huwei technologies and ZTE, both of China, are the second and the fifth-largest global manufacturers of telecom equipment (respectively). Similarly, Mexico's Grupo Bimbo is the largest bread maker in the world and Russia's United Company Rusal is the largest aluminum producer in the world (Boston Consulting Group, 2012). The 2011 list of the Forbes Global 2000 included 536 companies from emerging countries (Forbes, 2012). Similarly, 92 of emerging country firms are in the Financial Times Global 500 list. These 92 firms employ more than 9 million employees in their respective countries and global operations (FT Global 500, 2012). Some of these emerging multinationals (EMNEs) employ a significant proportion of their total employees outside their country of origin. For example Telefonica Brazil directly employs more than $50 \%$ of its total number of employees outside Brazil (www.telefonica.com). As the profile of emerging economies increase, so will their influence, and the global ranking of their MNEs. Many observers view these companies as the hidden engines of global trade and economic growth in the near future $(B C G, 2012)$.

While there are differences between Developed Market Multinational Enterprises (DMNEs) and EMNEs in terms of patterns of internationalization, some commentators 
expect a level of convergence between strategies of these two groups of global players (Ramamurti, 2012; Girod et al., 2009; Lessard and Lucea, 2009). Ramamurti (2012) argues that in time EMNEs may augment and enhance their ownership advantages to become more like DMNEs. Further, Ramamurti (2012) posits that the observed differences in ownership advantages between DMNEs and EMNEs may reflect differences in their evolution rather than differences stemming from their country of origin.

\section{A New Paradigm of Internationalization?}

Internationalization of emerging market firms can be examined in three different periods. EMNEs' internationalization in pre 2000 periods (the first and the second wave) were mainly triggered by home country factors aiming to diversify risk, or to avoid quotas (Lecraw, 1993). External factors at home played a significant role in this period and EMNEs internationalized their activities stage by stage through small-scale operations (Lecraw, 1977, 1993; Svetlicic, 2004; Jormanainen and Koveshnikov, 2012) which can be explained by the Uppsala theory of internationalization. EMNEs during the first wave invested mainly in niche markets in other developing countries (Kumar and McLeoid, 1981; Wells, 1983; Lecraw, 1977; Lall, 1983) which were not seen as attractive by developed country multinational enterprises (DMNEs) (Svetlicic, 2004). EMNEs, during the first two waves, heavily relied on their cost advantages and institutional knowledge of operating in similar markets to their own home countries (Kumar, and McLeod, 1981; Wells, 1983; Lecraw, 1993). It is argued that in the first wave MNEs from less developed countries had limited knowledge of global markets and a number of weaknesses compared to their developed country rivals. Commentators 
discussing the second wave of EMNEs' internationalisation point out that these firms expanded not only in other developing countries but also in developed markets with market seeking and resource seeking motives (Dunning, Van Hoesel and Narula, 1996; Mathews, 2002, 2006; Sachwald, 2001).

In the third wave however, starting in the 2000s, compared to their developing country predecessors EMNEs displayed a different pattern of internationalization (Luo and Tung, 2007; Gammeltoft 2008; Demirbag et al., 2010; Ramamurti, 2012; Madhok and Keyhani, 2012; Hennart, 2012;). In this period, FDI from emerging countries to developed countries were more focused on obtaining new sources of competitive advantage by acquiring strategic assets (Andreff, 2003; Gammeltoft, 2008: Deng, 2007; Rui and Yip, 2008). Thus EMNEs in the third wave of internationalization, particularly those from BRIC countries are more motivated by strategic assets that they need to close the capability gap that they have compared to DMNEs (Cuervo-Cazurra and Genc, 2008; Gammeltoft, 2008; Madhok and Keyhani, 2012; Guillen and Garcia-Canal, 2009; Hennart, 2012; Deng, 2012). Guillen and Garcia-Canal (2009, p. 27) argue that international expansion for EMNEs runs in parallel with capability upgrading process to catch up with their more advanced competitors to reduce this gap (see also Aulakh, 2007; Chittoor, Sarker, Ray, \& Aulakh, 2009; Demirbag, Tatoglu, \& Glaister, 2009; Luo, Sun, \& Wang, 2011; Madhok and Keyhani, 2012). In some other cases, due to competitive pressure and limited scope for growth in home markets, EMNEs may pursue overseas investment opportunities (Aulakh, 2007). Secondly, there has been a change in population ecology of EMNEs in this period. Small and medium sized EMNEs, and state owned MNEs from emerging countries became important actors of the third wave of 
internationalization (Luo and Tung, 2007; Demirbag, McGuinness and Altay, 2010; Demirbag, Tatoglu and Glaister, 2009). Another important feature of the third wave of internationalization of EMNEs is to do with their geographical dispersion. While in the first two waves, firms were mainly from Asia and Latin America, in the post 2000 era however we have seen an expansion of geographical dispersion of new players from emerging markets which include firms from Africa and post communist countries (Jormanainen and Koveshnikov, 2012; Luo and Tung, 2007). Furthermore, the internationalization pattern in this period has dramatically shifted from a step by step approach to more risk taking and aggressive forms such as direct acquisitions and setting up wholly owned subsidiaries without going through incremental steps envisaged by the Uppsala model of internationalization. All these differences from the previous waves, and particularly large acquisitions by EMNEs in the developed economies, has grabbed headlines in business media and excited interest from academic commentators (Peng, 2012; Hennart, 2012; Ramamurti, 2012; Guillen and Garcia-Canal, 2009; Bebenroth and Hemmert, 2013; Williamson and Raman, 2011; Cuervo-Cazurra, 2012).

However, EMNEs are not homogeneous group of firms, therefore, generalization should be done with caution. A breakdown of outward FDI by Brazil, Russia, India, China and South Africa indicate that there is not a single pattern of EMNEs location choice for their operations. While the majority of Indian (83\%), Russian (77\%) South African (73\%) and Brazilian (62\%) OFDI is in developed countries, up until recently, Chinese OFDI was mainly concentrated in Asia (63\%) and Latin America (19\%) (Campanario, Stal , \& de Silva 2012; Davies, 2012; Satyanand and Raghavendran, 2010; Kuznetsov, 2011). 
Although emerging markets are not a homogeneous group of countries, there appears to be some common dimensions in recent upsurge of internationalization of firms from these countries. These firms face some common challenges such as liability of emergingness due to their country of origin, existing knowledge gap between themselves and DMNEs, their poor image in terms of CSR and, at times, controversial political relations and agendas in developed markets. It is argued that these challenges motivate EMNEs to follow an accelerated internationalization through aggressive acquisitions in developed markets.(Madhok and Keyhani, 2012; Nair, Demirbag and Mellahi, 2013).

The recent upsurge of FDI by EMNEs, and their aggressive market entry methods have triggered a new debate on whether existing theories of internationalization are suitable for EMNEs' internationalization (Ramamurti, 2012: Madhok and Keyhani, 2012; Hennart, 2012; Peng; 2012; Guilen and Garcia-Canal, 2009; Luo and Tung; 2007; Aulakh, 2007; Chittoor, 2009, Gammeltoft, Barnard, \& Madhok, 2010). This involves critically examining existing theories of internationalization, particularly Dunning's eclectic paradigm and its pillars (OLI), and the stage model (Uppsala) of internationalization of the firm. We can discern three different arguments concerning the emerging pattern of EMNEs internationalization (Hennart, 2012; Ramamurti, 2012; Madhok and Keyhani, 2012; Rugman, 2009). The first group of these commentators argues that EMNEs do not possess many firm specific advantages (Rugman and Li, 2007; Rugman, 2009; Sethi, D., 2009). Based on assumptions of the OLI model, given that EMNEs do not possess firm specific advantages (FSAs), the first group argues that these firms will not be able to compete in global markets effectively. According to Rugman (2009), EMNEs rely on country specific advantages (CSAs) which are equally available 
to all firms present in those countries (including developed country MNE subsidiaries) therefore EMNEs competitive advantages are not sustainable in the long run.

The second group of commentators agrees that EMNEs may not necessarily possess FSAs in a conventional sense, nevertheless, despite their apparent lack of FSAs, these new challengers from emerging countries has expanded globally (Mathews, 2006; Luo, and Tung, 2007; Madhok and Keyhani, 2012). Amongst these commentators, Matthews (2002, 2006) argues that existing international business frameworks, particularly the "Ownership, Location and Internalization" (OLI) framework should be replaced with a framework that may explain EMNEs' internationalization pattern better. Matthew's argument is based on Asian MNEs' experience where he exposes weaknesses of the OLI model in explaining internationalization of new challengers (dragon MNEs) from Asia. Matthews (2006) proposes a new framework which is based on Linkage, Leverage and Learning (the LLL framework) and argues that the rapid internationalization of Asian MNEs can largely be explained by their linkage strategies (i.e., joint ventures, collaborative agreements) to leverage resources and utilize a clear learning strategy (cumulative learning). However the LLL framework does not explain how the learner (the EMNE) learns from and competes with DMNEs at the same time (Hennart, 2012; Ramamurti, 2009; Lessard and Lucea, 2009). Hennart (2012) on the other hand uses a transaction cost argument to explain internationalization of EMNEs, particularly for knowledge seeking investments. The rationale behind Hennart's argument is tightly linked with the nature and codifiability of knowledge intensive assets. When knowledge is tightly embedded in an organization, as Hennart (2012) argues, the feasibility of transferring such knowledge by other means would be limited, and the cost 
will be very high, therefore EMNEs will choose to acquire rather than use any other international market entry mode.

The third position amongst scholars about EMNEs internationalization is that these new challengers possess different types of FSAs, perhaps somewhat different than DMNEs' conventional type FSAs (Zeng and Williamson, 2007; Contractor, 2014; Hennart, 2012; Cuervo-Cazurra and Genc, 2008; Cuervo-Cazurra, 2012; Madhok and Keyhani, 2012; Ramamurti, 2012). Although EMNEs may not have the same conventional FSAs possessed by DMNEs, it is argued that they have different types of FSAs. Contractor (2014), in extending the argument on firm specific or competitive advantages of EMNEs, uses soft dimensions of enterprise including the mindset of top management, global perspectives, the need to catch-up by learning from alliance partners, and home country cultural traits such as emphasis on relationship. Large pools of technical talents and knowledge infrastructure that support certain types of offshore R\&D have long been used as a resource by DMNEs in home countries of EMNEs (Demirbag and Glaister, 2010). It is also argued that EMNEs' competitive advantage lies in their capabilities in terms of process innovations which allows them to compete in more developed markets (Williamson and Zeng, 2009; Contractor 2014) and their experiences and ability to understand emerging market customers and familiarity with less developed country institutional environment which enable them to be more agile and entrepreneurial (Madhok and Keyhani, 2012; Lessard and Lucea, 2009; Hennart, 2012; Ramamurti, 2012; Contractor 2014; Cuervo-Cazurra, Meyer, \& Ramamurti, 2014). Furthermore, entrepreneurial behavior and soft capabilities are also important FSAs for EMNEs (Girod et al., 2009; Madhok and Keyhani, 2012; Contractor, 2014). While DMNEs have FSAs in 
technical knowledge and focus on quantitative metrics to achieve lower cost advantages (Girod et al., 2009). EMNEs already have lower cost advantages at home (Madhok and Keyhani, 2012). Soft capabilities within EMNE organizations are seen as important factors which could be interpreted within the ownership advantage dimension $(\mathrm{O})$ of the OLI theory. These soft dimensions such as entrepreneurial alertness and learning agility do not only create cost advantages for EMNEs in the global markets, they also have significant impact on their internationalization and market entry mode (Contractor, 2014).

While EMNEs' motives to exploit their FSAs in other developing countries fit well with the OLI model, their expansion to more developed countries, particularly through acquisitions to create access to intangibles based FSAs pose some challenges to the OLI theory. Given recent large acquisitions during the third wave internationalization of EMNEs, Hennart (2012) argues that some of EMNEs' investments in developed markets are difficult to reconcile within the OLI model. These types of investments are focused on the acquisitions of intangibles when EMNEs clearly do not posses these FSAs. Generally asset oriented acquisitions fall into this category as these investments (acquisition of existing technologies, brands, systems, etc.) are not motivated by FSA exploitation. On the contrary, the main focus is to internalize these intangibles (Madhok and Keyhani, 2012; Hennart, 2012; Contractor, 2014). Thus as Hennart (2012) asks how do " these new challengers invest, learn from and successfully compete with DMNEs at the same time?" (Hennart, 2012). Based on this criticism, and others which has been highlighted by Ramamurti (2012) and Curevo-Cazurra (2012), the third group of commentators argue that existing international business theories need further extension to explain the new pattern of EMNEs' internationalization (Luo and Tung, 2007; Aulakh, 
2007; Guillen and Garcia-Canal, 2009; Madhok and Keyhani, 2012; Cuervo-Cazurra, 2012; Ramamurti, 2012; Hennart, 2012; Contractor, 2014; Williamson and Zeng, 2009).

\section{Production, People and Resources}

Emerging market MNCs that base their competitiveness on low cost production at home have, in the case of Africa, often entered countries and, where necessary adapted practices, not necessarily to harness local complementarities or even to access low cost labor, but rather owing to a desire to circumnavigate remaining tariff barriers (Simelane, 2008). Again, FDI flows may not necessarily reflect the righting of international imbalances (for example, between mega importing and mega exporting nations), but rather to shore up existing ones. Thus, fast growing emerging markets have increasingly prioritized access to raw materials, which has driven, major investments in the minerals sector in Africa. In other words, rather than spreading uniformity through disseminating successful export based manufacturing models worldwide, such FDI seeks to defend the existing export competitiveness of established low cost manufacturing exports countries. Within such a process, workers may both lose as producers and employees, even if they may gain through greater access to low cost manufactured goods (Boyer, 2010, p. 353).

A strand of the existing literature on Western MNCs suggests that their activities contribute to a decline in national homogeneity (Allen and Whitley, 2011, p. 97). However, they may choose to adopt practices to local national production regimes owing to the complementarities associated with them (Whitley, 2010). Whilst neo-liberal inspired accounts suggest that the US has pioneered an emerging global model (see Jensen, 1998), it is evident that what emerging market MNCs have been doing is very 
different. For example, the abovementioned export of semi- and unskilled labor by Chinese MNCs is quite different to any practice traditionally associated with MNCs (c.f. Tull, 2006). Traditionally, MNCs have relied on expatriates to fill specific skills gaps and/ or impart a common managerial culture. In recent years, the tightening up of border controls in the developed world has made it very much more difficult to use expatriates from emerging markets within the former. However, a converse trend is visible within much of the developing world; notably, relatively pliable local elites makes it very much easier to make usage of large numbers of expatriates across tropical Africa, even if many do not possess significant skills sets (c.f. Standing, 2011).

Whilst there is uncertainty as to the specific numbers involved, the numbers are certainly substantial: perhaps as many as 100000 Chinese workers in South Africa and a similar number in Zambia, a movement of peoples that is of historical and demographic significance. The usage of expatriate semi- and unskilled labor does confer immediate advantages. For example, it may enhance communication, resolving what could otherwise be serious language difficulties. Again, it may facilitate the transfer of particular models of work and employment relations, and reduce expectations gaps between workers and managers. At the same time, the model brings with it new risks.

\section{Institutions and Practice}

A key debate in international HR management is the extent to which firms adapt their HR policies and practices to suit specific national contexts, whether they keep them in line with the dominant ways of doing business in their parent country, or whether a 
new trans-global model of HR management is emerging (Glover and Wilkinson, 2007; Chang, Mellahi, \& Wilkinson, 2009).

So from an HRM perspective the ways in which MNCs from emerging economies manage their subsidiaries in developed countries are distinctive and different from the ways in which MNCs from developed countries manage their foreign subsidiaries. MNCs from emerging economies have to overcome the double hurdle of liability of foreignness (Hymer, 1976), and liability of country of origin. While liability of foreignness is unavoidable for both developed and emerging economies MNCs, liability of country of origin, and specifically disadvantages because of perceived weakness and lack of global dominance of the home country's economy, is more of an issue for MNCs from emerging economies than for MNCs from developed economies. Smith and Meiksins (1995) argue that the transfer of best practices between countries is influenced by a hierarchical order between national economies which creates dominance effects whereby "firms from countries lower in the hierarchy may perceive an interest in adopting practices from those based in more dominant economies. Conversely, firms in dominant economies may tend to assume that their practices are superior and capable of transfer to less dominant hosts" (Ferner et al., 2005). By the same token, one would expect managers and employees at subsidiaries in developed countries may believe that they possess superior managerial and technical knowledge to that of firms from emerging countries, and as a result may question the legitimacy and viability of managerial practices originating from a country they perceive as less developed and economically inferior to their own. In addition, a significant number of MNCs from emerging economies set up foreign subsidiaries in developed countries not only to exploit their home grown core capabilities, but also to 
augment them by learning from developed economies (Chang et al., 2009; Glover and Wilkinson, 2007). Thus, it is argued that the capacity to make use of similar organizational practices within different national locales is likely to optimize the firm's capacity; greater homogenization is likely to infuse greater efficiency (Kostova and Roth 2002, p. 215). While the diffusion of HR practices across transnational firms may be uneven and disjointed, it will gradually make for similarities in different national contexts; firms will try to enforce their own view of the most efficient, effective and appropriate ways of accommodating HRM in other countries (Barry and Wilkinson, 2011).

Accounts within the broad institutionalist tradition suggest that within specific national contexts, firm-level practices will gradually become homogenous or 'isomorphic' with the national context (Kostova and Roth 2002, p. 215). Three forms of isomorphism may be identified: coercive (where the firm is forced to adopt specific practices, such as through force of law); mimetic (specific practices associated with success in individual firms are copied by others); or normative (behavior is tailored to fit what is considered suitable for the specific environment) (Kostova and Roth 2002, p. 216; Brewster et al., 2004). Recent institutional writings (cf. Whitley, 2010; Brewster et al., 2004, Wilkinson and Wood 2012) have pointed to an emerging body of evidence that global economic pressures do not seem to have translated into uniform outcomes in terms of HR practices, despite intensified global pressures to liberalization.

Both institutional and cultural approaches argue that MNCs have adapted their activities in line with local practices (Kostova and Roth 2002, p. 215). As noted earlier, this process does reflect a particular path dependence - countries or regions tend to 
follow distinct trajectories, inter alia associated with specific sets of managerial and, specifically, HR practices, which are not easily altered and take time to adapt. MNCs entering a new country need to tailor/adapt their policies and practices to be more responsive to local expectations and realities, even if it means departing from longestablished organizational practices.

Writing from within the institutionalist tradition, Whitley (1999, p. 126) argues that MNCs are unlikely to change their existing practices unless foreign operations constitute a very large component of organizational activities, with these activities being concentrated in a national business system very different to - but more developed than that of the country of origin.

Given the extent of barriers to the altering of corporate strategies and practices, it is likely that many firms will infuse elements of practices associated with the principal national contexts in which they operate. In other words, firms face conflicting pressures towards the homogenization of practices around different national models, making for an uneven and dynamic integration process (Gooderham et al., 1998). Hence, it is important to understand the extent to which the policies of MNCs are molded and impacted by specific national contexts. It has been variously suggested that MNCs mould their policies in the different locations in which they operate according to the specific cultural and/ or institutional setting, that they inevitably mimic the policies that predominate in their parent countries, or that they are gradually converging towards a common international model of HRM. However, there is a growing body of critical research that suggests that there remains considerable variety in the HR policies followed by MNCs, reflecting a combination of pressures towards localization, internationalization and 
ethnocentricity. It could be argued that weaker institutional arrangements in many emerging markets might allow MNCs a greater range options for experimentation. Again, it has been argued that MNCs will amend their strategies according to the specific advantages occurred by particular markets, which could encompass natural resources, cheap labor or developed local production regimes (Morgan, 2012; Whitley, 2010).

\section{Emerging Issues}

Cooke, F.L. (2014) explores the nature and consequences of the increased internationalization of Chinese firms recent years. However, she observes that $t$ studies that compare Chinese multinational corporations (MNCs) on sectoral lines and their human resource management (HRM) policies and practices remain limited. In seeking to fill this gap, her study examines the HRM practices of Chinese MNCs and the extent to which these are shaped by the institutional factors that are specific to industries. The paper is located within the broad political economy tradition, making use of contemporary institutional approaches. It argues that, in examining Chinese MNCs, it is important to take account of the role of the government and a wider range of other institutional players in shaping the HRM policies and practices of these firms. She highlights the role of the developmental state in orchestrating economic growth through the extension of investment locales and production sites beyond China, and the organization of labor in ways that seek to minimise the labor-capital conflicts at the point of production. Through, in many cases, taking local labor out of the production system and deploying dispatched Chinese labor instead, whose mobility is tied to specific employment arrangements, workers from both countries are rendered immobile 
politically and logistically, giving the management a relatively free hand to pursue their economic goals.

Arp, F. (2014) points us to the phenomenon of emerging market organizations appointing foreign executives from distant cultural contexts to headquarter positions His research explains why foreign executives despite significant cultural distance are appointed to local headquarter positions, what they contribute, and why these positions are not filled with local executives. And in doing so his study extends the liability of foreignness (LOF) conceptualization from organizations to individuals. The findings suggest that there can be advantage as well as liability of foreignness at the individual level. FELOs' advantage of foreignness is illustrated not only by their usefulness to local organizations in the portrayal of internationalization. The relative outsider status of FELOs gives them the opportunity to identify and address neglected issues, manage change and take on roles that local executives find too controversial for themselves. FELOs' liability of foreignness is reflected in the risk of them being made scapegoats due to their relative outsider status.

Jackson, T. (2014) points to recent negative reports of Chinese engagement in Africa especially in the area of HRM. He notes that wider socio-political motives may modify commercial motives, but also explores how Confucian relationalism may modify the way its conceptualization of humanism is applied to African workers. Nonetheless, the way Chinese managers engage with African workforces may be very different to Western managers. He notes a disparity between China's professed strategic level of engagement and what happens at organizational level, indicating that many Chinese 
organizations may be contributing to employment, but not to up-skilling of workers, or mutual learning. He finds evidence of engagement with local communities at programme and project level, but not at the level of work organizations themselves. Jobs are created, but conditions are often poor. Chinese managers bring with them to Africa their values, assumptions, management styles and attitudes, which suggest a high degree of paternalism, regard for hierarchy, low regard for trade unions, and perhaps even a relationalism that may disadvantage outsiders.

Thite, Budhwar, and Wilkinson (2012) argue that whilst an abundance of low cost labor is often the starting point of competitive advantage for many of the emerging markets' MNCs, it is the optimum configuration of people, processes and technology that defines how they leverage their intangible resources. Based on case studies of four Indian IT services MNCs, they identify five key HR roles, namely, strategic business partner, guardian of culture, builder of global workforce and capabilities, champion of processes, and facilitator of employee development The analysis also highlights that the HR function in Indian IT services MNCs faces several challenges in consolidating the early gains of internationalization, such as lack of decentralized decision making, developing a global mindset, localization of workforce and developing a global leadership pipeline. Based on these findings, they propose a framework outlining the global HR roles pursued by emerging IT services MNCs, the factors influencing them, and the challenges facing their HR function for future research.

Zhu, J.S. and colleagues (2014) note that while many studies have demonstrated the existence of the country of origin effect and how this effect interacts with other factors in shaping MNCs practices, there has been rather less investigation of different 
forms of country of origin effect, the mechanisms through which this effect occurs, or country of origin effect on MNCs from emerging markets. Their study explores how country of origin effect manifests in Chinese MNCs' preparation for managing host country labor relations. Based on a study of 21 Chinese MNCs, they argue that country of origin effect in relation to Chinese MNCs mainly manifests indirectly through transfer of management ethos and competitive disadvantage generated from the home base, rather than in the form of direct practice transfer as commonly suggested in the current literature. The major mechanism through which country of origin effect plays out is the mindset of managers, rather than formally established corporate control instruments. They suggest that managers responsible for overseas investment decisions and the management of overseas labor relations should be wary of relying on their past experience, and need to adapt their thinking to the local context. Chinese MNCs would benefit from adopting a more independent HR structure, with headquarters HR department focusing more on ensuring future leaders, at both headquarters and subsidiaries, are sensitive to and equipped to deal with global challenges as well as local conditions.

Ataullaha, Hang and Sahota (2014) examine the impact of the cross-border acquisitions made by firms from emerging markets on employee productivity and employment growth. They point out that extant literature suggests that cross-border acquisitions enable emerging market firms to obtain new skills and knowledge-intensive assets, which, in turn, may increase productivity. However, their analysis suggests that, in the case of emerging market MNCs, cross-border acquisitions reduce employee 
productivity and have a limited impact on employment growth. Cross-border acquisitions in less-developed countries and in culturally distinct countries are particularly likely to be associated with reduced productivity. Overall, their findings cast doubt on the idea that cross-border acquisitions enable emerging market firms to improve the productivity of human capital. They suggest that, given cross-border acquisitions do not improve employee productivity, emerging market acquirers need to reevaluate their HRM strategies in order to facilitate the diffusion and sharing of skills and knowledge during the post-acquisition period. Thus, an important task of an effective HRM system is to minimize the adverse impact of uncertainties created by cross-border acquisitions in culturally distinct nations.

Andreeva, Festing, Minaeva, and Muratbekova-Touron (2014) analyze variations in the HRM policies and practices of Russian MNEs, contrasting developed and developing countries. They show that Russian MNEs tend to adopt Western style HRM practices in most areas. However, these MNEs differ radically in their choices of IHRM approaches. Many of these differences depend on the countries these MNEs target in their international expansion. In developing CIS countries, the approaches adopted by Russian MNEs typically reflect a feeling of superiority. However, in developed countries and in non-CIS developing countries, Russian MNEs actively promote a mix of global best practices and local HRM practices. They did not find instances of the reverse transfer of management practices from subsidiaries in developed countries to the MNEs' headquarters or any examples of cross-pollination among subsidiaries. Notably, they did not find a country-of-origin effect, which may support the notion that an MNE's homecountry context is not necessarily as homogenous as suggested in previous literature This 
may be a general tendency for MNEs originating in settings characterized by major institutional changes, such as Russia.

\section{Conclusions}

This special issue explores the HRM strategies, polices and practices of MNEs from emerging markets. A common them running through the papers is that country of origin effects do not appear to be very pronounced. Rather than spreading a unique and nationally dominant set of $\mathrm{HR}$ recipes abroad, there appears to be a tendency to either emulate the practices of Western MNEs, or adopt as a default option, the type of authoritarian paternalism widespread in the developing world. In doing so, unique features of national HRM in country of origin (for example, within Russia, there remain deeply embedded legacies of state socialist era) are often lost. An important exception would be in subsidiaries of Russian MNEs located in those countries of the 'near abroad' where similar institutional legacies have persisted. Another difference would be the case of those Chinese MNEs who import even unskilled labor from their home country; this approach enables them to sidestep local labor regulation, whilst being relatively remote from regulation in their country of origin.

A second and related theme is that in most instances, best practice appears elusive. In other words, there is little evidence of emerging market MNCs systematically pursing sophisticated sets of HR practices that have been proven to (or at least of have a high likelihood of) add value to the firm. Nor is there much evidence of sophisticated new HRM approaches being developed or rolled out by emerging market MNEs. This does not mean that this might not be a future possibility; however, this would have to 
accommodate both complex and sometimes contradictory country of origin regulations and informal governmental expectations of prominent firms, and the often weak and incomplete nature of institutional supports in developing countries of domicile.

Nonetheless, emerging market MNEs have become an increasingly visible feature of the global business ecosystem. Even if they opt for low value added practices or outright labor substitution, this is likely to impact on local and international competitors, through driving down labor standards, and/or undermining the competitive position of the latter two groups. At the same time, the political linkages and social capital of more established players is not to be underestimated; even if emerging market MNEs have been able to forge deals on highly favorable terms with host country elites, this does not mean that such deals will necessary prove durable. This would suggest that the present state of relative freedom from institutional effects from country of origin and/ or domicile might prove transitory, encouraging the adoption and dissemination of more strategic approaches to HRM.

Adrian Wilkinson is a professor and director of the Centre for Work, Organisation and Wellbeing at Griffith University, Australia. Prior to his 2006 appointment, he worked at Loughborough University in the United Kingdom, where he was a professor of human resource management. He holds visiting professorships at Loughborough University, Sheffield University, and the University of Durham, and is an academic fellow at the Centre for International Human Resource Management at the Judge Institute of the University of Cambridge. Wilkinson has written/edited 20 books, more than 150 articles in refereed journals, and numerous book chapters. In 2011 he was elected as an academician of the Academy of Social Sciences in recognition of his contribution to the field. In 2012, he was shortlisted by HR Magazine for the HR Most Influential International Thinker award.

Geoffrey Wood is Professor of International Business and Associate Dean at Warwick Business School, University of Warwick. He currently is Honorary Professor of the University of the Witwatersrand, and Visiting Professor at Nelson Mandela University, both in South Africa, and Adjunct Professor at Monash University and at Griffith University, Australia. Geoffrey Wood has served as Commissioned Researcher for the 
South African Truth and Reconciliation Commission. He has authored/co-authored/edited some dozen books, and over one hundred and forty articles in peer-reviewed journals (including journals such as Work and Occupations, Work Employment and Society, Organization Studies, Human Relations, British Journal of Industrial Relations, Human Resource Management (US), etc.). He has had numerous research grants from funding councils (e.g. ESRC), government departments (e.g. US Department of Labour), charities (e.g. Nuffield Foundation) and the labour movement (e.g. the ITF). He is Editor-in-Chief of the British Journal of Management.

\section{References}

Allen, M. and Whitley, R. (2011), 'Internationalization and sectoral diversity', in Lane, C. and Wood, G. (eds) Capitalist Diversity and Diversity within Capitalism. London: Routledge.

Andreff, W. (2003), 'The newly emerging TNCs from economies in transitions: a comparison with third world outward FDI', Transnational Corporations, 12, 2, pp. $73-118$.

Andreeva, T., Festing, M., Minbaeva, D. B. and Muratbekova-Touron, M. (2014), The Janus Faces of IHRM in Russian MNEs. Human Resource Management, doi: 10.1002/hrm.21615

Arp, F. (2014) 'Emerging Giants, Aspiring Multinationals, and Foreign Executives: Leapfrogging, Capability Building, and Competing with Developed Country Multinationals', Human Resource Management (in press)

Ataullah, A., Le, H. and Sahota, A. S. (2014), Employee Productivity, Employment Growth, and the Cross-Border Acquisitions by Emerging Market Firms. Hum. Resour. Manage.. doi: 10.1002/hrm.21619

Aulakh, P. S. (2007), 'Emerging multinationals from developing economies: motivations, paths and performance', Journal of International Management, 13, pp. 235-240.

Barry, M. and Wilkinson, A. (eds) (2011), Research Handbook of Comparative Employment Relations. Cheltenham: Edward Elgar.

BCG Report (2012), The 2012 BCG 100 New Global Challengers.

Bebenroth, R. and Hemmert, M. (2013), 'Are emerging market multinationals milking their cross-border acquisition targets? A study of inbound Japanese and Korean M \& As', Kobe University RIBE Discussion Paper Series, DP2013-06. 
Boyer, R. (2010), "'The collapse of finance, but labour remains weak", Socio-Economic Review, 8, 2, pp. 348-353.

Business Week (2006), 'Emerging giants', Cover story, July 31.

Campanario, M.A. Stal, E. and de Silva, M.M. (2012), Outward FDI from Brazil and its policy context. Columbia FDI Profiles, Vale Columbia Center.

Chang, Y. Y., Mellahi, K. and Wilkinson, A. (2009), 'Control of subsidiaries of MNCs from emerging economies: the case of Taiwanese MNCs in the UK', International Journal of Human Resource Management, 20, 1, pp. 75-95.

Chittoor, R. (2009), 'Internalization of emerging economy firms - need for new theorizing', Indian Journal of Industrial Relations, 45, 1, pp. 27-40.

Chittoor, R., Sarkar, M.B., Ray, S. and Aulakh, P.S. (2009), 'Third-world copycats to emerging multinationals: institutional changes and organizational transformation in the Indian pharmaceutical industry', Organization Science, 20, 1, pp. 187-205.

Contractor, F. (2014), "Punching above their weight": the sources of competitive advantage for emerging market multinationals', in Demirbag, M. and Yaprak, A. (eds) Handbook of Emerging Market MNEs. Cheltenham: Edward Elgar.

Cooke, F. L. (2014), Chinese Multinational Firms in Asia and Africa: Relationships With Institutional Actors and Patterns of HRM Practices. Hum. Resour. Manage.. doi: $10.1002 / \mathrm{hrm} .21612$

Curvo-Cazurra, A. (2012), 'Extending theory by analyzing developing country multinational companies: solving the goldilocks debate', Global Strategy Journal, 2, pp. 153-167.

Cuervo-Cazurra, A. and Genc, M. (2008), 'Transforming disadvantages into advantages: developing-country MNEs in the least developed countries', Journal of International Business Studies, 39, 6, pp. 957-979.

Cuervo-Cazurra, A., Meyer, K. and Ramamurti, R. (2014), 'Explaining internationalization of emerging economy multinationals: the relative resource specialization of firm and environment mechanism', in Demirbag, M. and Yaprak, A. (eds) Handbook of Emerging Market MNEs. Cheltenham: Edward Elgar.

Davies, K. (2012), Outward FDI from China and its Policy Context. Columbia FDI Profiles, Vale Columbia Center.

Demirbag, M. and Glaister, K.W. (2010), 'Factors determining offshore location choice for R\&D projects: a comparative study of developed and emerging regions', Journal of Management Studies, 47, 8, pp. 1534-1560. 
Demirbag, M., McGuinness, M. and Altay, H. (2010), 'Perceptions of institutional environment and entry mode: FDI from an emerging country', Management International Review, 50, 2, pp. 207-240.

Demirbag, M., Tatoglu, E. and Glaister, K.W. (2009), 'Equity-based entry modes of emerging country multinationals: lessons from Turkey', Journal of World Business, 44, 4, pp. 445-462.

Deng, P. (2012), 'Accelerated internationalization by MNCs from emerging economies: determinants and implications', Organizational Dynamics, 41, pp. 318-326.

Deng, P. (2007), 'Investing for strategic resources and its rationale: the case of outward FDI from Chinese companies', Business Horizons, 50, 1, pp. 71-81.

Dunning, J.H., van Hoesel, R. and Narula, R. (1996), 'The 'new' wave of FDI from developing countries: the case of Taiwan and Korea'. Available at $<$ http://arno.unimaas.nl/show.cgi?fid=137>.

Economist (2008), 'Wind of change, emerging-market multinationals', January 10.

Ferner, A., Almond, P. and Colling, T. (2005) "Institutional Theory and the CrossNational Transfer of Employment Policy: The Case of 'Workforce Diversity' in US Multinationals", Journal of International Business Studies, 3, 3, pp. 304-21.

Financial Times (2013), FT Global 500. Available at <http://www.ft.com/indepth/ft500>.

Forbes (2012), Global 2000 Leading Companies. Available at $<$ http://www.forbes.com/global2000/list/>.

FTSE (2012), 'Emerging markets'. Available at <http://www.ftse.co.uk/Indices/FTSE_Emerging_Markets/index.jsp>.

Gammeltoft, P. (2008), 'Emerging multinationals: outward FDI from the BRICS countries', International Journal of Technology and Globalisation, 4, 1, pp. 5-22.

Gammeltoft, P., Barnard, H. and Madhok, A. (2010), 'Emerging multinationals, emerging theory: macro-and-micro-level perspectives', Journal of International Management, 16, pp. 95-101.

Gaur, A. and Kumar, V. (2010), 'Internationalization of emerging market firms: a case for theoretical extension', in Devinney, T., Pederesen, T. and Tihanyi, L. (eds) Advances in International Management, 23. Emerald Group Publishing Limited.

Girod, S.J.G., Belin, J.B. and Thomas, R.J. (2009), 'Are emerging market multinationals creating the global models for the future?', Accenture Institute for High Performance. 
Glover, L.A. and Wilkinson, A. (2007), 'Worlds colliding: the translation of modern management practices within a UK based subsidiary of a Korean-owned MNC', International Journal of Human Resource Management, 18, 8, pp. 1437-1455.

Guillen, M.F. and Garcia-Canal, E. (2009), 'The American model of the multinational firm and the 'new' multinationals from emerging economies', Academy of Management Perspectives, 23, 2, pp. 23-35.

Hennart, J.F. (2012), 'Emerging market multinationals and the theory of multinational enterprise', Global Strategy Journal, 2, pp. 168-187.

Hoskisson R.E., Eden, L., Lau C.M. and Wright, M. 2000, 'Strategy in emerging economies', The Academy of Management Journal, 43, 3, pp. 249-267.

Hoskisson, R.E., Wright, M., Filatotchev, I. and Peng, M. (2013), 'Emerging multinationals from mid-range economies: the influence of institutions and factor markets', Journal of Management Studies.

Hymer, S. H. (1960). The International Operations of National Firms: A Study of Direct Foreign Investment. Cambridge (Ma.): MIT Press.

Jackson, T. (2014), Employment in Chinese MNEs: Appraising the Dragon's Gift to SubSaharan Africa. Hum. Resour. Manage.. doi: 10.1002/hrm.2156

Jensen, M. 1998, Foundations of Organizational Strategy. Boston: Harvard University Press.

Jormanainen, I. and Koveshnikov, A. (2012), 'International activities of emerging market firms: a critical assessment of research in top international management journals', Management International Review, 52, pp. 691-725.

Khanna, T. and Palepu, K. G. (2006), 'Emerging giants: building world-class companies in developing countries', Harvard Business Review, 84, pp. 2-10.

Kostova, Tatiana and Kendall Roth (2002), 'Adoption of an organizational practice by subsidiaries of multinational corporations: Institutional and relational effects', Academy of Management Journal 45, pp. 215-233.

Kumar, K. and McLeod, M.G. (eds) (1981), Multinationals from Developing Countries. Lexington, MA: Lexington Books.

Kuznetsov, A. (2011), Outward FDI from Russia and its Policy Context. Columbia FDI Profiles, Vale Columbia Center.

Lall, S. (1983), 'The new multinationals: the spread of third world enterprises', Chichester: Wiley. 
Lecraw, D. (1977), 'Direct investment by firms from less developed countries', Oxford Economic Papers, November, pp. 442-457.

Lecraw, D.J. (1993), 'Outward direct investment by Indonesian firms: motivation and effects', Journal of International Business Studies, 24, 3, pp. 589-600.

Lessard, D. and Lucea, R. (2009), 'Mexican multinationals: insights from CEMEX', in Ramamurti, R. and Singh, J. (eds) Emerging Multinationals from Emerging Markets. Cambridge UK: Cambridge University Press.

Luo, Y. and Tung, R.L. (2007), 'International expansion of emerging market enterprises: a springboard perspective', Journal of International Business Studies, 38, 4, pp. 481-498.

Luo, Y., Sun, J. and Wang, S.L. (2011), 'Emerging economy copycats: capability, environment and strategy', Academy of Management Perspectives, 25, 2, pp. 3756.

Madhok, A. and Keyhani, M. (2012), 'Acquisitions as entrepreneurship: asymmetries, opportunities, and the internationalization of multinationals from emerging economies', Global Strategy Journal, 2, pp. 26-40.

Mathews, J.A. (2002), Dragon Multinationals. Oxford: Oxford University Press.

Mathews, J.A. (2006), 'Dragon multinationals: new players in 21st century globalization'. Asia Pacific Journal of Management, 23, pp. 5-27.

Morgan, G. (2012), 'International business, multinationals and national business systems', in Wood, G. and Demirbag, M. (eds) Handbook of Institutional Approaches to International Business. Cheltenham: Edward Elgar.

MSCI (2012), MSCI Barra Index. Available at <http://www.msci.com/products/indices/>.

Nair, S.R., Demirbag M. and Mellahi, K. (2013), 'Reverse knowledge transfer: a survey of acquisitions by Indian MNEs', Academy of International Business Annual Meeting, Istanbul, 3-7 July.

Peng, M. (2012), 'Global strategy of emerging multinationals from China', Global Strategy Journal, 2, pp. 97-107.

Ramamurti, R. (2012), 'Commentaries: what is really different about emerging market multinationals', Global Strategy Journal, 2, pp. 41-47.

Ramamurti, R. (2009), 'What have we learned about emerging-market MNEs?', in Ramamurti, R. and Singh. J. (eds) Emerging Multinationals from Emerging Markets. Cambridge UK: Cambridge University Press. 
Rugman, A.M. (2009), 'Theoretical aspects of MNEs from emerging countries', in Ramamurti, R. and Singh, J. (eds) Emerging Multinationals in Emerging Markets, Cambridge University Press: Cambridge.

Rugman, A.M. and Li, J. (2007), 'Will China's multinationals succeed globally or regionally', European Management Journal, 25, 5, pp. 333-343.

Rui H. and Yip, G.S. (2008), 'Foreign acquisitions by Chinese firms: a strategic intent perspective', Journal of World Business, 43, 2, pp. 213-226.

Sachwald, F. (ed) (2001), Going Multinational: the Korean Experience of Direct Investment, 9, Psychology Press.

Satyanand, P.N. and Raghavendran, P. (2010), Outward FDI from India and its Policy Context. Columbia FDI Profiles, Vale Columbia Center.

Sethi, D. (2009), 'Are multinational enterprises from the emerging economies global or regional?', European Management Journal, 27, 5, pp. 356-365.

Simelane, X. (2008), 'Textiles and employee relations in Swaziland', Employee Relations, 30, 4, pp. $452-465$.

Smith, C. and Meiskins, P. (1995) „System, Society and Dominance effects in CrossNational Organizational Analysis ${ }^{\mathrm{ee}}$, Work, Employment and Society. 9. 2, pp. 241267

Standing, G. (2011), The Precariat: The New Dangerous Class. London: Bloomsbury Academic.

Svetlicic, M. (2004), 'Transition economies' multinationals: are they different from third world multinationals', Proceedings of the 8th International conference on Global Business and Economic Development, Guadalajara, January.

Thite, M., Wilkinson, A. and Shah, D. (2012), 'HRM strategies and practices across subsidiaries in multinational corporations from emerging economies - a conceptual perspective', Journal of World Business, 47, 2, pp. 251-258.

Thite, M., Budhwar, P., and Wilkinson, A. (2014) 'Global HR Roles and Factors Influencing Their Development: Evidence From Emerging Indian IT Services Multinationals', Human Resource Management. doi:10.1002/hrm.21621.

Tull, D. (2006), 'China's engagement in Africa', Journal of Modern African Studies, 44, 3, pp. 459-479.

UNCTAD (2006), 'World investment report 2006'.

UNCTAD (2010), 'World Investment Report 2010’. 
Wells, L. (1983), 'Third world multinationals: the role of foreign direct investment from developing countries', Cambridge, MA: MIT Press.

Whitley, R. (2010), 'Changing competition in market economies', in Morgan, G., Campbell, J., Crouch, C., Pedersen, O. and Whitley, R. (eds) The Oxford Handbook of Comparative Institutional Analysis. Oxford: Oxford University Press.

Williamson, P.J. and Raman, A.P. (2011), 'How China resets its global acquisition agenda', Harvard Business Review, April, pp. 109-114.

Williamson, P.J. and Zeng, M. (2009), 'Chinese multinationals: emerging through new global gateways', in Ramamurti, R. and Singh, J. (eds) Emerging Multinationals from Emerging Markets. Cambridge UK: Cambridge University Press.

Wilkinson, A and Wood, G (2012,) 'Institutions and Employment Relations - the state of the art', Industrial Relations: a journal of economy and society, vol. 51, no. 2, pp. 373-488.

Wright, M., Filatotchev, I., Hoskisson, R.E. and Peng, M.W. (2005), 'Guest editors' introduction - strategy research in emerging economies: challenging the conventional wisdom', Journal of Management Studies, 42, 1, pp. 1-33.

Zeng, M. and Williamson, P. (2007), Dragons at Your Door: How Chinese Cost Innovations is Disrupting Global Competition. Boston, MA: Harvard Business School Press.

Zhu, J. S., Zhu, C. J. and De Cieri, H. (2014), Chinese MNCs' Preparation for HostCountry Labor Relations: An Exploration of Country-of-Origin Effect. Human Resourse Management, doi: 10.1002/hrm.21613. 